\title{
PENERAPAN PEMBELAJARAN KOOPERATIF TIPE MAKE A MATCH BERBANTUAN MEDIA POP UP BOOK UNTUK MENINGKATKAN HASIL BELAJAR MUATAN PELAJARAN IPS SISWA KELAS IV SD NEGERI SALATIGA 10 SEMESTER 2 TAHUN PELAJARAN 2017/2018
}

\author{
Arline Antanaz Sary ${ }^{1}$, Suroso 2 , Yustinus ${ }^{3}$ \\ 1Pendidkan Guru Sekolah Dasar, UKSW Salatiga, 292014046@student.uksw.edu \\ 2Pendidkan Guru Sekolah Dasar, UKSW Salatiga, Suroso.sltg@gmail.com \\ 3Pendidkan Guru Sekolah Dasar, UKSW Salatiga Ytinus@staff.uksw.edu
}

\begin{tabular}{l} 
INFO ARTIKEL \\
\hline Riwayat Artikel: \\
Diterima: 27-03-2018 \\
Disetujui: 10-04-2018 \\
\hline Kata Kunci: \\
Make A Match \\
Media Pop Up Book \\
Hasil Belajar Muatan \\
pelajaran IPS
\end{tabular}

\section{A. LATAR BELAKANG}

Hasil belajar merupakan hal yang penting dalam setiap mata pelajaran, baik hasil belajar yang berupa angka atau penerapan dalam kehidupan sehari-hari. Hasil belajar yang mampu mencapai angka tinggi didukung dengan proses belajar. Muatan pelajaran IPS di SD menjadi salah satu mata pelajaran yang dianggap cukup sulit untuk dipelajari. Siswa sering kali mengeluh karena materi yang sulit dipahami, cakupan materi yang terlalu luas dan tidak menyukai muatan pembelajarannya. Hal tersebut dapat berdampak pada hasil belajar yang siswa peroleh.

Ilmu Pengetahuan Sosial (IPS) menjadi pelajaran yang berpengaruh dalam kehidupan sehari-hari. IPS menjadi salah satu mata pelajaran yang diberikan dari tingkat SD/MI/SDLB sampai dengan SMP/MTs/SMPLB. Pada jenjang SD/MI muatan pelajaran IPS diberikan dengan berupa materi geografi, sejarah sosiologi dan ekonomi. Melalui muatan pelajaran IPS siswa diharapkan mampu menjadi warga negara yang demokratis dan bertanggung jawab serta dapat menanamkan sikap toleransi terhadap keragaman budaya Indonesia. Karena Indonesia mempunyai beragam budaya yang berbeda-beda.

Dalam proses pembelajaran guru seharusnya juga menjalankan modifikasi model pembelajaran. Salah satunya pembelajaran kooperatif. Suprijono (2009:54) mengatakan "Pembelajaran kooperatif adalah konsep yang lebih luas meliputi semua jenis kerja kelompok termasuk bentuk-bentuk yang lebih dipimpin oleh guru atau diarahkan oleh guru”. Menurut Solihatin dan Raharjo (2009) pemanfaatan kelompok memaksimalkan belajar mereka dan belajar anggota lainnya kelompok tersebut. Sedangkan menurut Sharan (2012:561) "Pembelajaran kooperatif adalah pendekatan yang berpusat pada kelompok dan berpusat pada siswa untuk pengajaran dan pembelajaran di kelas

Salah satu pembelajaran kooperatif yang dapat dimodifikasi dalam muatan pelajaran IPS yaitu make a 
match. Menurut Febriana (2011) make a match bertujuan untuk menumbuhkan sikap saling menghormati, menumbuhkan sikap tanggung jawab, meningkatkan percaya diri dalam menyelesaikan masalah.

Agar siswa lebih tertarik pada materi yang diajarkan, bisa digunakan media yang dapat mempermudah dalam pembelajaran. Salah satunya adalah gambar. Karena untuk mendatangkan contoh riilnya terlalu susah. Jadi untuk mempermudah saat proses pembelajaran dapat menggunakan gambar. Gambar sangat penting digunakan dalam memperjelas pengertian pada siswa. Dengan menggunakan gambar siswa dapat lebih memperhatikan terhadap benda atau hal yang belum pernah dilihatnya yang berkaitan dengan pelajaran.

Pembelajaran yang terjadi dilapangan masih berupa pembelajaran konvensional yaitu ceramah. Endrayanto dan Harimurti (2014:31) mengatakan "kegiatan pembelajaran yang diharapkan siswa tentu akan berkaitan dengan proses dan hasil. Sebenarnya guru hanya menjadi fasilitator dalam membimbing dan mengarahkan pembelajaran. Guru tidak menjadi satusatunya sumber belajar yang dapat dimanfaatkan, tetapi siswa dapat memanfaatkan dengan sumber belajar lain.

Berdasarkan observasi di SD Negeri Salatiga 10 yang dilakukan pada tanggal 22 Januari 2018. Menunjukkan bahwa masih terlihat permasalahan pada muatan pelajaran IPS antara lain siswa ramai sendiri dan mengobrol dengan teman menujukkan siswa tidak memperhatikan pelajaran Saat diberi pertanyaan guru siswa hanya diam saja dan tidak menjawab. Guru sudah memberikan kesempatan kepada siswa untuk bertanya materi yang belum dipahami, siswa menjawab sudah paham. Kemudian guru memberikan latihan soal untuk dikerjakan dan hasil yang diperoleh siswa tidak memenuhi KKM dan jawaban yang ditulis sangat jauh dari pertanyaan dan jawaban yang diharapkan. Jumlah ketuntasan yang didapat siswa juga terbilang banyak yaitu sebesar 20 atau $60 \%$ dari total keseluruhan siswa yaitu 35 siswa. Berdasarkan latar belakang masalah diatas maka dalam penelitian ini dirumuskan masalah yaitu apakah pembelajaran kooperatif tipe make a match berbantuan media pop up book dapat meningkatkan hasil belajar muatan pelajaran IPS kelas IV?

\section{B. METODE EPENELITIAN}

Jenis penelitian yang dilakukan peneliti yaitu Penelitian Tindakan kelas (PTK). Penelitian Tindakan kelas yaitu Classroom Action Research dilakukan untuk meningkatkan mutu pembelajaran di kelas. Penelitian ini dilakukan secara kolaboratif, yaitu dengan melakukan kolaborasi atau kerjasama dengan guru kelas dan peneliti. Penelitian ini dilakukan pada jumlah 35 siswa kelas IV di SD Negeri Salatiga 10.
Variabel Penelitian dan Definisi Operasional Variabel Penelitian

Variabel penelitian dibagi menjadi dua yaitu variabel bebas dan variabel terikat.

1. Varibael bebas (x)

Variabel bebas yaitu variabel yang memengaruhi faktor-faktor yang diukur. Variabel bebas dalam penelitian ini yaitu pembelajaran kooperatif tipe make a macth berbantuan media pop up book.

2. Variabel terikat $(\mathrm{y})$

Variabel terikat merupakan variabel yang diamati atau diukur oleh peneliti dalam penelitiannya. Variabel terikat dalam penelitian ini yaitu hasil belajar muatan pelajaran IPS siswa kelas IV.

\section{Definisi Operasional}

Pembelajaran Kooperatif tipe make a match yaitu suatu model yang menugaskan siswa untuk mencari pasangan kartu yang siswa dapatkan. Sebelum permainan dimulai guru menjelaskan materi dengan dengan media pop up book. Media pop up book berisi gambar-gambar terkait materi yang akan dipelajari. Guru juga bisa menambahkan materi dengan mengaitkan dilingkungan sekitar siswa. Setelah menjelaskan materi kemudian masuk ke permainan make a match. Sebelumnya guru membagi siswa menjadi dua kelompok. Kelompok A mendapatkan kartu soal dan kelompok B mendapatkan kartu jawaban. Setelah itu siswa mencari pasangan sesuai dengan kertu soal dan kartu jawaban.

Dalam mengumpulkan data penelitian, peneliti menggunakan dua teknik yaitu tes dan observasi.

1. Tes

Dalam penelitian ini alat yang digunakan untuk menguji atau mengukur instrumen penelitian. Soal yang digunakan berupa soal pilihan ganda yang berjumlah 20 item soal.

2. Observasi

Observasi digunakan untuk mengukur seberapa berhasilnya suatu sintak yang digunakan peneliti. Dalam penelitian ini guru berperan sebagai pengajar dengan menggunakan make a match berbantuan media pop up book. Sedangkan peneliti sebagai observer atau pengamat.

\section{Hipotesis Tindakan}

Berdasarkan kerangkan berpikir dan pedapat diatas, maka hipotesis penelitian tindakan kelas dirumuskan yaitu penerapan pembelajaran kooperatif tipe make a match berbantuan media pop up book dapat meningkatkan hasil belajar muatan IPS kelas IV SD Negeri Salatiga 10 Tahun Pelajaran 2017/2018 


\section{HASIL DAN PEMBAHASAN Hasil Penelitian \\ Deskripsi Awal}

Berdasarkan hasil observasi awal, permasalahan yang diidentifikasi pada dasarnya yaitu proses pembelajaran hanya menggunakan pembelajaran konvesional atau ceramah. Guru menjelaskan materi dengan ceramah dan siswa mencatat kembali apa yang dijelaskan oleh guru. Setelah itu guru memberikan soal latihan untuk mengukur seberapa pahamnya siswa mengenai materi yang telah dijelaskan. Masih ada siswa yang hanya diam dan mendengarkan saja tanpa memahami apa yang telah dijelaskan oleh guru. Hal tersebut akan berdampak pada hasil belajar siswa. Agar lebih jelasnya mengenai hasil belajar siswa dapat dilihat tabel dibawah ini:

TABEL 1

HASIL BELAJAR SISWA MUATAN PELAJARAN IPS SISWA KELAS IV

SD NEGERI SALATIGA 10

\begin{tabular}{cccc}
\hline $\begin{array}{c}\text { KKM } \\
\text { Matematika }\end{array}$ & Ketuntasan & Frekuensi & Presentase \\
\hline$\geq 75$ & Tuntas & 15 & $40 \%$ \\
\hline$<75$ & Tidak Tuntas & 20 & $60 \%$ \\
\hline Total & 24 & $100 \%$ \\
\hline \multicolumn{2}{c}{ Rata-Rata } & \multicolumn{2}{c}{70,2} \\
\hline Nilai Tertinggi & \multicolumn{2}{c}{95} \\
\hline Nilai Terendah & \multicolumn{2}{c}{55} \\
\hline
\end{tabular}

Dapat dilihat pada tabel diatas bahwa hasil belajar mauatan pelajaran IPS terbilang rendah karena jumlah siswa yang mencapai ketuntasan sebesar $60 \%$ dari total keseluruhan.

\section{Deskripsi Pelaksanaan Tindakan Siklus I}

Pelaksanaan siklus I akan dilakukan dalam dua pertemuan. Pada pertemuan pertama dan pertemuan kedua akan dilakukannya penelitian dengan make a match berbatuan media pop up book dan diberikan soal latihan dan soal evaluasi. Kompetensi dasar yang digunakan pada peneltian ini yaitu 3.2 mengidentifikasi keragaman sosial, ekonomi, budaya, etnis, dan agama di provinsi setempat sebagai identitas bangsa Indonesia serta hubungannya dengan karakteristik ruang.

\section{Siklus I}

\section{a. Perencanaan}

Kegiatan yang dilakukan pada siklus I pertemuan pertama mencakup beberapa hal sebagai berikut:

1. Menemukan masalah penelitian yang terjadi di lapangan. Pada fase ini dilakukan melalui pengamatan langsung di kelas IV SD Negeri Salatiga 10 ketika pembelajaran berlangsung.

2. Meminta izin kepada pihak sekolah sekaligus guru kelas untuk melaksanakan kegiatan penelitian.

3. Penyusunan Rencana Pelaksanaan (RPP) sesuai dengansiktak make a match dan dipadukan dengan media pop up book. Pada bagian ini dilakukan kerjasama dengan guru kelas yang dalam menyusun RPP yang akan digunakan dalam proses pembelajaran.

4. Pembuatan media pop up book untuk mendukung pembelajaran berdasarkan RPP yang telah disusun.

5. Pembuatan kartu soal dan kartu jawaban.

6. Penyusunan instrumen tes hasil belajar muatan pelajaran IPS.

7. Membuat lembar observasi guru yang nantinya untuk mengukur keberhasilan sintak yang dilakukan.

\section{b. Pelaksanaan dan Observasi}

Pada tahap ini dilakukan tindakan penelitian secara langsung sesuai dengan RPP yang telah disusun. Pengamatan dan pelaksanaan dilakukan bersamaan dengan kegiatan pembelajaran berlangsung. Tahap pelaksanaan dilakukan pada tanggal 22 Maret 2018 dimulai pada jam 07.00 08.10. Pada pertemuan pertama semua siswa kelas IV ada 2 siswa yang tidak berangkat dengan alasan sakit. Sebelum pembelajaran dimulai, seperti biasa siswa berdoa, hormat kepada bendera merah putih, dan menyanyikan lagu Indonesia raya dengan bimbingan guru. Kemudian guru melakukan absensi dan apersepsi untuk masuk dalam pembelajaran. Guru menanyakan kepada siswa mengenai pekerjaan yang dimiliki setiap orang tua siswa. Guru menanyakan kembali mengenai pekerjaan yang dihasilkan terkait pekerjaan orang tua siswa.

Selanjutnya guru menyampaikan tujuan pembelajaran yang akan dicapai pada hari itu juga yaitu 1) dengan media pop up book siswa dapat menyebutkan berbagai macam kegiatan ekonomi dengan benar; 2) dengan media pop up book siswa dapat mengelompokkan jenis-jenis pekerjaan yang menghasilkan barang dan jasa; 3) dengan media pop up book siswa dapat mengidentifikasi status sosial berdasarkan pekerjaan disekitar lingkungan sampai provinsi; 4) dengan media pop up book siswa dapat menyebutkan kebudayaan dilingkungan tertentu berdasarkan mayoritas pekerjaan masyarakat dilingkungan sekitar sampai provinsi. Guru memperlihatkan media pop up book kepada siswa. Tetapi pada saat itu guru tidak berkeliling untuk memperlihatkan media pop up book. Guru menjelaskan media dan mengaitkan dengan lingkungan sekitar siswa. Guru membagi siswa menjadi dua kelompok. Kelompok A yang mendapatkan kartu soal dan kelompok B yang mendapatkan kartu jawaban. Kemudian guru menjelaskan cara bermain make a match. Guru memperlihatkan kartu soal dan kartu jawaban kepada siswa. Guru menunjukkan satu kartu soal dan satu 
kartu jawaban untuk dijadikan contoh. Guru membagikan kartu soal dan kartu jawaban kepada satu siswa. Setiap siswa hanya mendapatkan satu kartu. Guru memberikan waktu 10 menit untuk mencari pasangan. Siswa berdiskusi untuk mencari pasangan kartu yang mereka dapatkan. Suasana kelas menjadi ramai dan siswa sulit dikendalikan. Setelah waktu habis, guru mencocokan kartu soal dan kartu jawaban. Setelah sudah dicocokan kemudian guru memberikan tugas untuk dikerjakan pada saat itu juga.

Pada pertemuan kedua dilaksanakan pada tanggal 23 Maret 2018 jam 09.35-10.45 WIB. Pertemuan kedua masih sama ada 1 siswa yang tidak berangkat karena alasan sakit. Setelah guru melakukan absensi guru menyampaik tujuan pembelajaran ayng akan dicapai. Kemudian guru menjelaskan materi dengan media pop up book. Guru menjelaskan permainan make a match kepada siswa. Guru juga mencontohkan cara permainan dengan menukar kelompok. Kelompok yang mendapatkan soal pada pertemuan pertama akan mendapatkan kartu jawaban pada pertemuan kedua. Setelah dibagi, siswa berdiskusi untuk mencari pasangan kartu yang mereka dapatkan. Keadaan kelas berbeda dengan pertemuan pertama karena siswa lebih paham cara bermain mencari pasangan. Setelah permainan selesai, guru mencocokan jawaban setiap pasangan kartu. Kemudian guru memberikan soal evaluasi kepada siswa untuk mengukur seberapa paham mengenai materi pada pertemuan pertama dan kedua.

Agar lebih jelas mengenai hasil belajar muatan pelajaran IPS kelas IV pada tahap siklus I, dapat dilihat tabel dibawah ini:

TABEL 2

HASIL BELAJAR SISWA MUATAN PELAJARAN IPS SISWA KELAS IV SIKLUS I SD NEGERI SALATIGA 10

\begin{tabular}{cccc}
\hline $\begin{array}{c}\text { KKM } \\
\text { Matematika }\end{array}$ & Ketuntasan & Frekuensi & Presentase \\
\hline$\geq 75$ & Tuntas & 22 & $64 \%$ \\
\hline$<75$ & Tidak Tuntas & 12 & $36 \%$ \\
\hline Total & 24 & $100 \%$ \\
\hline \multicolumn{2}{c}{ Rata-Rata } & \multicolumn{2}{c}{76,5} \\
\hline \multicolumn{2}{c}{ Nilai Tertinggi } & 93 \\
\hline \multicolumn{2}{r}{ Nilai Terendah } & 58 \\
\hline
\end{tabular}

\section{c. Refleksi}

Berdasarkan hasil wawancara, dokumentasi dan nilai evaluasi, dapat disimpulkan dari beberapa hasil yaitu pembelajaran yang dilakukan cukup menarik saat mencari pasangan kartu soal dan kartu jawaban. Tetapi saat mencari pasangan kartu ada beberapa siswa yang meyerah karena bingung. Hal lain yang memperlihatkan pembelajaran kurang maksimal yaitu saat evaluasi kartu. Siswa yang berebut untuk melaporkan kepada guru dan suasanan kelas menjadi semakin ramai. Untuk mengatasi permasalahan ini, dianjurkan saat mecocokan kartu siswa diharapkan untuk duduk terlebih dahulu dan guru memanggil pasangan siswa satu persatu didepan kelas. Atau saat berdiskusi mencari pasangan, guru memberikan kesempatan satu baris terlebih dahulu untuk mencari pasangan.

Setelah dilakukkam evaluasi pada siklus 1 diperoleh nilai yang belum mencapai indikator yang disusun, sehingga masih perlu adanya penelitian siklus 2 untuk mendapatkan hasil yang benar-benar meyakinkan. Maka dipustuskan untuk melakukkan pembelajaran yang maksimal disiklus 2.

\section{Deskripsi Pelaksanaan Tindakan Siklus II}

Pada siklus II sintak yang dilakukan berbeda dengan siklus I. Pada pertemuan pertama dan pertemuan kedua akan dilakukannya penelitian dengan make a match berbatuan media pop up book dan diberikan soal latihan dan soal evaluasi. Kompetensi dasar yang digunakan pada peneltian ini masih sama seperti siklis I yaitu 3.2 mengidentifikasi keragaman sosial, ekonomi, budaya, etnis, dan agama di provinsi setempat sebagai identitas bangsa Indonesia serta hubungannya dengan karakteristik ruang.

\section{Siklus II}

\section{a. Perencanaan}

Pada tahap perencanaan siklus 2, RPP siklus I yang telah disusun digunakan lagi pada tahap siklus II. Kompetensi dasar yang diambil masih sama dengan siklus I yaitu 3.2 mengidentifikasi kegiatan ekonomi dan hubungannya dengan berbagai bidang pekerjaan serta kehidupan sosial dan budaya dilingkungan sekitar sampai provinsi. Media yang digunakan juga masih sama seperti siklus I yaitu menggunakan media pop up book, kartu soal dan kartu jawaban. Menyiapkan soal evaluasi untuk dikerjakaan saat pertemuan kedua dan menyusun lembar observasi guru untuk mengukur seberapa sukses sintak yang dijalankan.

\section{b. Pelaksanaan dan Observasi}

Siklus 2 pertemuan pertama dilaksanakan pada hari Selasa 27 Maret 2018 pada pukul 07.00-08.10 WIB yang dihadiri 34 siswa kelas IV. Pada pertemuan pertama siklus II mengambil kompetensi dasar yang sama dengan siklus I yaitu mengidentifikasi kegiatan ekonomi dan hubungannya dengan berbagai bidang pekerjaan serta kehidupan sosial dan budaya dilingkungan sekitar sampai provinsi. Pada siklus II guru seperti biasa mengawali dengan membuka pembelajaran dan iikuti dengan mengucapkan salam kepada siswa kelas IV. Selanjutnya melakukan absensi untuk mengetahui kehadiran siswa yang hadir pada hari itu. Sebelum memulai pembelajaran guru menanyakan kembali mengenai materi yang minggu lalu yaitu kegiatan ekonomi. Sebagian siswa masih 
belum paham mengenai kegiatan ekonomi. Kemudian guru menyampaikan tujuan pembelajaran.

Kegiatan inti pada pertemuan pertama siklus II seperti siklus I. Guru menunjukkan media pop up book dan menjelaskan materi dengan mengaitkan keghidupan sehari-hari. Guru tidak hanya terpaku dengan gambar di media pop up book karena dengan gambar terbatas. Guru bisa memberikan contoh yang lain yang berada disekitar siswa. Dalam permainan make a match berbeda dengan siklus I yaitu guru membentuk kelompok menjadi 2 yaitu kelompok A yang mendapatkan kartu soal dan kelompok B yang mendapatkan kartu jawaban. Dalam mencari pasangan berbeda dengan siklus I yaitu siswa yang mendapatkan kartu soal mencari pasangannya perbaris tempat duduk. Tidak semua siswa yang mendapatkan kartu soal mencari secara bersama-sama. Jadi perbedaan dengan siklus 1 dalam mencari pasangan.

Pada pertemuan kedua dilaksanakan pada hari Rabu tanggal 28 Maret 2018 pukul 07.00-08.10 WIB. Untuk kegiatan awal masih sama seperti pertemuan pertama yaitu guru menanyakan mengenai materi minggu lalu. Kemudian guru menyampaikan tujuan pembelajaran. Kegiatan inti pada pertemuan kedua sama seperti kegiatan inti pertemuan pertama siklus II. Guru menjelaskan materi dengan bantuan media pop up book dan mengaitkan pembelajaran dengan lingkungan sekitar. Guru melakukan tanya jawab mengenai materi yang dipelajari. Setelah itu guru membagikan kartu soal dan kartu jawaban kepada siswa. Siswa mencari pasangan dengan cara sama seperti pada pertemuan pertama. Kemudian guru mencocokkan kartu pasangan yang didiskusikan siswa. Siswa yang benar mendapatkan reward berupa hadiah sebagai motivasi dalam pembelajaran. Setelah permainan selesai guru memberikan soal evaluasi kepada siswa. Lima belas menit sebelum pelajaran berakhir, siswa beserta guru menyimpulkan isi dari pembelajaran. Soal evaluasi digunakan untuk mengukur seberapa paham siswa mengenai materi pada pembelajaran hari ini.

Agar lebih jelas mengenai hasil belajar muatan pelajaran IPS kelas IV pada tahap siklus II, dapat dilihat tabel dibawah ini:

TABEL 3

HASIL BELAJAR SISWA MUATAN PELAJARAN IPS SISWA KELAS IV SIKLUS II SD NEGERI SALATIGA 10

\begin{tabular}{cccc}
\hline $\begin{array}{c}\text { KKM } \\
\text { Matematika }\end{array}$ & Ketuntasan & Frekuensi & Presentase \\
\hline$\geq 75$ & Tuntas & 32 & $94 \%$ \\
\hline$<75$ & Tidak Tuntas & 2 & $6 \%$ \\
\hline Total & & 24 & $100 \%$ \\
\hline \multicolumn{2}{c}{ Rata-Rata } & \multicolumn{2}{c}{94} \\
\hline Nilai Tertinggi & \multicolumn{2}{c}{95} \\
\hline Nilai Terendah & \multicolumn{2}{c}{60} \\
\hline
\end{tabular}

\section{c. Refleksi}

Pada siklus II dari hasil pengamatan pembelajaran menggunaka make a match sudah berjalan baik sesuai sintak dengan perubahan kecil misalnya pada saat menemukan pasangan dengan perbaris tempat duduk. Situasi lebih terkontrol dan tidak ramai. Siswa juga terlihat lebihs semangat daripada saat siklus I yang bingung mencari pasangannya. Dari hasil evaluasi siklus kedua diperoleh hasil yang lebih meningkat daripada siklus I dan sudah memenuhi indikator yang ditetapkan. Untuk itu disepakati tidak akan melanjutkan pada siklus III karena dokumentasi yang diperoleh sudah mencukupi.

\section{Analisis Data}

Berdasarkan penelitian yang dilakukan, hasil yang diperoleh terbukti menunjukkan peningkatan hasil belajar muatan belajar IPS. Terbukti banyak siswa yang mengalami peningkatan dalam mengembangkan hasil belajar muatan pelajaran IPS yang didesain dengan pembelajaran kooperatif tipe make a match berbantuan media pop up book pada setiap siklusnya.

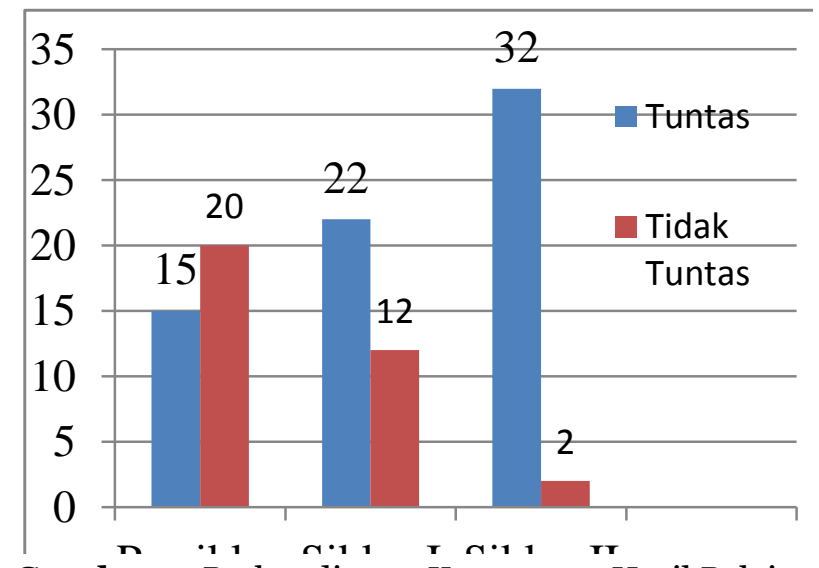

Gambar 1. Perbandingan Ketuntasan Hasil Belajar Siswa Muatan Pelajaran Ips Siswa Kelas IV Sd Negeri Salatiga 10

Berdasarkan gambar diagram diatas terlihat jelas bahwa ketuntasan hasil belajar siswa mencapai peningkatan dari prasiklus, siklus I, dan siklus II. Ketuntasan hasil belajar mauatan pelajaran IPS siswa kelas IV SD Negeri Salatiga 10 sebelum dilakukannya tindakan adalah 15 siswa. Setelah dilakukannya tindakan menggunakan make a match berbantuan media pop up book pada siklus I ketuntasan hasil belajar muatan pelajaran IPS mencapai 22 siswa. Selanjutnya setelah dilanjutkan lagi pada siklus II ketuntasan hasil belajar muatan pelajaran IPS mencapai 32 siswa. Berdasarkan gambar diagram yang terlihat terjadi penurunan yang tidak tuntas pada siklus I dan siklus II. Siswa yang belum mencapai ketuntasan hasil belajar pra siklus sebesar 20 siswa, Setelah digunakannya pembelajaran kooperatif tipe make a match berbantuan media pop up book pada siklus I turun menjadi 12 siswa, dan dilanjutkan lagi 
pada siklus II turun menajdi 2 siswa. Rata-rata hasil belajar muatan pelajaran IPS mengalami peningkatan. Peningkatan rata-rata hasil belajar muatan pelajaran IPS siswa dapat dilihat sebagai berikut:

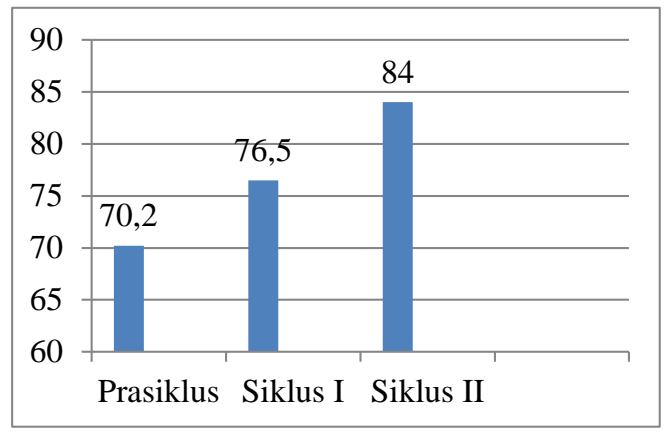

Gambar 2. Perbandingan Rata-Rata Hasil Belajar Siswa Muatan Pelajaran Ips Siswa Kelas IV Sd Negeri Salatiga 10

Berdasarkan gambar diagram diatas dapat dilihat bahwa rata-rata hasil belajar muatan pelajaran IPS mencapai peningkatan dari prasiklus, siklus I dan siklus II. Rata-rata hasil belajar muatan pelajaran IPS siswa kelas IV SD Negeri Salatiga 10 pada prasiklus sebesar 70,2. Setelah digunakannya pembelajaran kooperatif tipe make a match berbantuan media pop up book pada siklus I naik sebesar 76,5 dan dilanjutkan lagi pada siklus II mengalami kenaikan sebesar 84 .

Hal lain juga terlihat jelas bahwa ketuntasan hasil belajar siswa mencapai peningkatan dari prasiklus, siklus I, dan siklus II. Ketuntasan hasil belajar muatan pelajaran IPS siswa kelas IV SD Negeri Salatiga 10 sebelum dilakukannya tindakan adalah 15 siswa. Setelah dilakukannya tindakan menggunakan make a match berbantuan media pop up book pada siklus I ketuntasan hasil belajar muatan pelajaran IPS mencapai 22 siswa. Selanjutnya setelah dilanjutkan lagi pada siklus II ketuntasan hasil belajar muatan pelajaran IPS mencapai 32 siswa. Berdasarkan gambar diagram yang terlihat terjadi penurunan yang tidak tuntas pada siklus I dan siklus II. Siswa yang belum mencapai ketuntasan hasil belajar pra siklus sebesar 20 siswa, Setelah digunakannya pembelajaran kooperatif tipe make a match berbantuan media pop up book pada siklus I turun menjadi 12 siswa, dan dilanjutkan lagi pada siklus II turun menajdi 2 siswa. Rata-rata hasil belajar muatan pelajaran IPS mengalami peningkatan.

\section{PEMBAHASAN}

Dari hasil analisis komparatif baik pra siklus maupunsiklus I dan siklus II menunjukkan adanya peningkatan hasil belajar muatan pelajaran IPS. Dapat dilihat hasil analisis pra siklus hanya sejumlah 15 siswa dari jumlah keseluruhan siswa yaitu 35 siswa. Pada siklus I terjadi kenaikan ketuntasan hasil belajar muatan pelajaran IPS yaitu sejumlah 22 siswa dari 35 siswa.
Pada tahap siklus II terjadi kenaikan ketuntasan hasil belajar siswa yaitu 32 siswa dari 35 siswa. Hal ini terlihat jelas perbandinganya dari pra siklus, siklus I dan siklus II. Hasil analisis komparatif pada rata-rata juga terlihat kenaikan dari prasiklus, siklus I dan siklus II yaitu 70,2 ke siklus I sebesar 76,5 dan siklus II 84. Tindakan yang dilakukan sudah berhasil, karena indikator kinerja yang ditetapkan dalam penelitian yaitu siklus I mencapai $65 \%$ dan siklus II mencapai $94 \%$ yang termasuk dalam kategori tuntas. Pada siklus I indikator kinerja sudah tercapai, karena mencapai persentase ketuntasan ketuntasan $65 \%$ untuk mendapatkan hasil yang lebih meyakinkan dilakukan tindakan lagi pada siklus II dengan perencanaan yang lebih matang. Setelah dilaksankan siklsu II dan indikator kinerja tercapai, disepakati untuk tidak melanjutkan pada tahap siklus III Hal tersebut dikarenakan keterbatasan waktu dan biaya serta tindakan yang dilakukan sudah tercapai.

Dari hasil peneitian terdapat perbedaan yang cukup terlihat antara pembelajaran konvensional yang sering dilakukan oleh guru dan pembelajaran make a match dengan bantuan media pop up book. Saat pembelajaran konvensional siswa hanya mendengarkan dan jika ditanya oleh guru siswa hanya diam saja. Jika menjelaskan materi masih ada siswa yang ramai sendiri atau melamun. Sedangkan saat pembelajaran menggunakan make a match dan didukung dengan media pop up book, siswa sangat antusias saat mendengarkan pejelasan dan sangat aktif saat mencari pasangan.

Hasil penelitian tindakan kelas untuk meningkatkan hasil belajar muatan pelajaran IPS melalui pembelajaran kooperatif tipe make a match berbantuan media pop up book pada kelas IV SD Negeri Salatiga 10 terbukti berhasil. Terjadi peningkatan pada hasil belajar siswa kelas IV pada muatan pelajaran IPS. Pada penelitian yang relevan juga sudah terbukti jika penggunaan make a match dapat meningkatkan hasil belajar muatan pelajaran IPS. Contohnya penelitian Aldriyanti, Novi dkk (2017) dalam penelitian "Penerapan Model Pembelajaran Kooperatif Tipe Make A Match untuk Meningkatkan Hasil Belajar IPA Siswa Kelas III SD Negeri 42 Pekanbaru menyimpulkan bahwa penerapan model pembelajaran kooperatif tipe make a match dapat meningkatkan hasil belajar siswa kelas III SD Negeri 42 Pekanbaru. Jadi dapat disimpulkan bahwa penerapan pembelajaran kooperatif tipe make a match berbantuan media pop up book untuk meningkatkan hasil belajar muatan pelajaran IPS siswa kelas IV SD Negeri Salatiga 10 semester 2 tahun pelajaran 2017/2018 dapat dikatakann berhasil karena terjadi peningkatan pada hasil belajar muatan pelajaran IPS.

Hasil penelitian yang telah diperoleh dapat menjawab hipotesis yaitu bahwa penerapan pembelajaran kooperatif tipe make a match berbantuan media pop up book dapat meningkatkan hasil belajar 
muatan IPS kelas IV SD Negeri Salatiga 10 Tahun Pelajaran 2017/2018.

Berdasarkan pembahasan dan penjelasan mengenai pembelajaran tipe make a match berbantuan media pop up book, dapat dirumuskan implikasi teorits dan implukasi praktis sebagai berikut:

\section{Implikasi Teoritis}

Setelah membandingkan pembelajaran koopertaif tipe make a match berbantuan media pop up book dengan penelitian sebelumnya adalah sejalan dan saling melengkapi. Penerapan pembelajaran koopertaif tipe make a match berbantuan media pop up book disesuaikan dengan standar proses. Meskipun penerapan pembelajaran koopertaif tipe make a match berbantuan media pop up book mengalami perubahan akan tetapi tetap disesuaikan dengan karakteristik siswa, sehingga dapat meningkatkan pemahaman, pengalaman, dan menambah ilmu pengetahuan serta siswa mampu menerapkan konsep yang telah dipelajari dalam kehidupan sehari-hari.

2. Implikasi praktis

Pembelajaran kontekstual melalui pembelajaran koopertaif tipe make a match berbantuan media pop up book dapat meningkatkan hasil belajar siswa muatan pelajaran IPS . Siswa yang semula belum tuntas setelah diadakan tindakan dengan menggunakan pembelajaran kooperatif tipe make a match berbantuan media pop up book menjadi tuntas melalui siklus I dan siklus II. Penerapan pembelajaran koopertaif tipe make a match berbantuan media pop up book dilakukan agar siswa dapat memperoleh nilai diatas KKM.

\section{E. SIMPULAN DAN SARAN Simpulan}

Berdasarkan bab-bab sebelumnya maka dapat disimpulkan bahwa langkah-langkah yang dimiliki pada pembelajaran koopertaif tipe make a match berbantuan media pop up book dapat meningkatkan hasil belajar muatan pelajaran IPS. Hal ini nampak adanya peningkatan ketuntasan belajar siswa prasiklus 15 atau 40\%, siklus I 22 atau 64\%, dan siklus II 32 atau $94 \%$. Hal lain juga terjadi peningkatan rata-rata hasil belajar siswa prasiklus 70,2, siklus I 76,5, siklus II 84 .

\section{SARAN}

1) Bagi Guru

Guru dapat menjadikan pembelajaran koopertaif tipe make a match berbantuan media pop up book sebagai salah satu alternatif atau solusi untuk meningkatkan hasil pembelajaran. Karena pembelajaran koopertaif tipe make a match berbantuan media pop up book dapat digunakan untuk semua muatan pelajaran.

2) Bagi Sekolah

Penerapan pembelajaran koopertaif tipe make a match berbantuan media pop up book dalam pelaksanaan kegiatan belajar mengajar dapat dijadikan referensi sebagai upaya meningkatkan mutu dan pembelajaran di SD Negeri Salatiga 10.

\section{3) Bagi Peneliti Selanjutnya}

Pemilihan pembelajaran koopertaif tipe make a match berbantuan media pop up book supaya direncanakan lebih matang dan bisa dimodifikasi dengan media pembelajaran lain agar menajdi lebih inovatif.

\section{UCAPAN TERIMAKASIH}

Penulis mengucapkan teimakasih kepada semua pihak yang telah berkontribusi dalam penelitian ini, khusunya guru dan siswa SD Negeri Salatiga 10, Bapak Suroso dan Bapak Yustinus selaku pembimbing.

\section{DAFTAR PUSTAKA}

1) Solihatin, Etin dan Raharjo. 2005. Cooperative Learning : Analisis Model Pembelajaran IPS. Jakarta:Bumi Aksara

2) Suprijono, Agus. 2009. Cooperative Learning :Teori dan Aplikasi PAIKEM. Yogyakarta: Pustaka Pelajar

3) Sharan, Shlomo. 2012. Handbook of Cooperative Learning. Yogyakarta: Familia editor Daru Wijaya Alih Bahasa : Sigit Prawoto

4) Endrayanto, Herman Yosep Sunu dkk . 2014. Penilaian Belajar Siswa di Sekolah. Palembang:Kanisius

5) Febriana (2011). Semarang. Unnes https://journal.unnes.ac.id/nju/index.php/kreatif/article Vview/1678 diakses tanggal 27 Februari 2018

6) Aldriyanti, Novi dkk (2017). Penerapan Model Pembelajaran Kooperatif Tipe Make A Match untuk Meningkatkan Hasil Belajar IPA Siswa Kelas III SD Negeri $42 \quad$ Pekanbaru. https://jom.unri.ac.id/index.php/JOMFKIP/article/view $\lcm{17704}$ diakses pada tanggal 23 Februari 2018

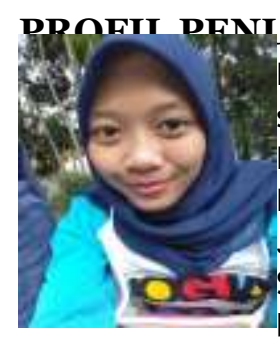

ILIS UTAMA

Penulis bernama lengkap "Arline Antanaz sary". Lahir di Dusun Sulur Desa Sulursari Kecamatan Gabus Kabupaten Grobogan Provinsi Jawa Tengah pada tanggal 15 Januari 1996 dari pasangan Suwanto dan Suwarli. Penulis adalah anak kedua dari 2 bersaudara. Pendidikan sekolah dasar dimulai dari SD Negeri Sulursari 01 Gabus pada tahun 2003 - 2008. Setelah itu melanjutkan pendidikan sekolah menengah ke SMP Negeri Gabus 01 pada tahun 2008 - 2011 dan terakhir di MAN Grobogan 01 pada tahun 2011 - 2014. Kemudian penulis melanjutkan studi ke perguruan tinggi Universitas Kristen Satya Wacana Salatiga FKIP PGSD pada tahun 2014.

Kritik, saran, maupun hal-hal yang berkaitan dengan kelanjutan atau pengembangan dari hasil penelitian ini bisa dikirim ke email penulis di: arlineantanazsary@gmail.com 